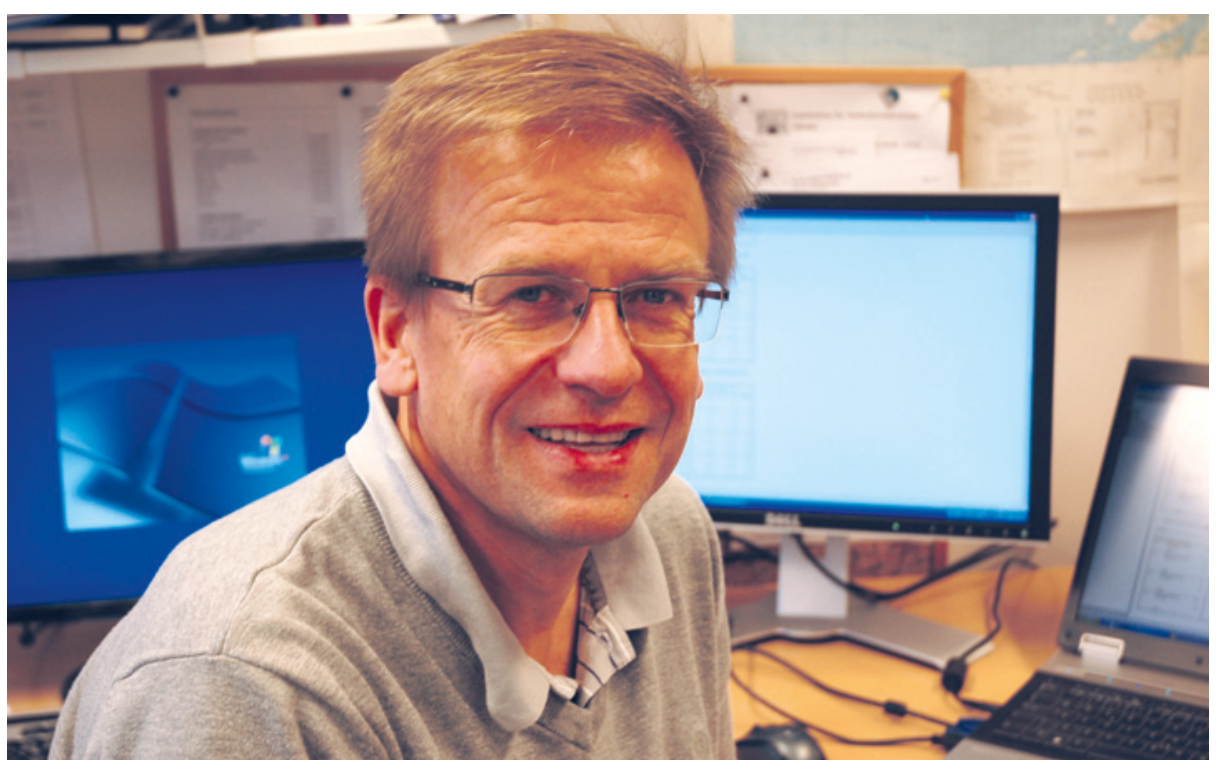

Førsteforfatter Trond Iversen. Foto privat

\title{
Steroidinjeksjon uten virkning ved isjias
}

Kaudal epidural injeksjon av steroider har ingen effekt ved isjias,

ifølge en randomisert norsk multisenterstudie.

Isjias er definert som ryggsmerter med utstråling til underekstremitetene, ledsaget av nevrologiske symptomer eller utfall som passer med påvirkning av en lumbal nerverot. Årsaken er ofte lumbalt skiveprolaps. Isjias går som regel over av seg selv, men hvis symptomene vedvarer i mer enn 12 uker, anbefales ofte kirurgisk behandling. Epidural injeksjon av steroider er en mindre invasiv, men mye brukt behandlingsmetode. Likevel er effekten lite dokumentert. Nå har norske forskere vurdert effekten av kaudal epidural steroidinjeksjon i en randomisert multisenterstudie (1).

116 pasienter med isjias ble randomisert til kaudal epidural steroidinjeksjon, kaudal epidural injeksjon av fysiologisk saltvann eller placeboinjeksjon, dvs. subkutan injeksjon av saltvann. Det ble gitt to injeksjoner med to ukers mellomrom, og det primære utfallsmålet var bedring målt ved ODI-skår (Oswestry disability index).

Pasientene som ble behandlet med placeboinjeksjoner, ble gradvis bedre - med estimert reduksjon av ODI-skår på 4,7, 11,4 og 14,4 etter henholdsvis seks, 12 og 52 uker. En behandlingsintensjonsanalyse viste ingen statistisk signifikante forskjeller mellom gruppene. Det samme gjaldt sekundære utfallsmål som ryggsmerter, utstrålende smerter og livskvalitet.

- Designen - med én gruppe som fikk placeboinjeksjon, på engelsk gjerne omtalt som «sham», og én gruppe som fikk epidural injeksjon med fysiologisk saltvann er en styrke ved denne studien, sier Trond Iversen ved Fysikalsk- og rehabiliterings- medisinsk avdeling ved Universitetssykehuset Nord-Norge, som er førsteforfatter av artikkelen. - Det har vært fremsatt hypoteser om at injeksjon med fysiologisk saltvann av en viss mengde $i$ epiduralrommet kan ha en behandlingseffekt i seg selv. Dette har gjort det vanskelig å tolke tidligere randomiserte studier. Vår studie viser tydelig at verken saltvannsinjeksjon eller steroidinjeksjon gir bedre resultat enn placebo. Kaudale epidurale injeksjoner kan derfor ikke anbefales som behandling av isjias. Vi har imidlertid ikke studert effekten av epidural steroidinjeksjon rettet direkte mot rotkanalen for den aktuelle nerveroten, sier Iversen.

\section{Forskning på isjias}

Artikkelen er skrevet av Trond Iversen, Tore K. Solberg, Bertil Romner, Tom Wilsgaard, Jos Twisk, Audny Anke, Øystein Nygaard, Toralf Hasvold og Tor Ingebrigtsen. Iversen og Anke arbeider ved Fysikalsk- og rehabiliteringsmedisinsk avdeling ved Universitetssykehuset NordNorge. Artikkelen skal inngå i Iversens doktoravhandling. Tor Ingebrigtsen er veileder. Pasientene ble rekruttert fra fem norske sentre.

\section{Erlend Hem}

erlend.hem@medisin.uio.no

Tidsskriftet

\section{Litteratur}

1. Iversen T, Solberg TK, Romner B et al. Effect of caudal epidural steroid or saline injection in chronic lumbar radiculopathy: multicentre, blinded randomised controlled trial. BMJ 2011; 343: d5278.
Ordforklaringer

Oswestry disability index (ODI) er et godt utprøvd skjema for å måle funksjonsstatus hos pasienter med korsryggssmerter. Det har gode psykometriske egenskaper og er oversatt til en rekke språk. Jo høyere skår, desto større funksjonsnedsettelse.

Behandlingsintensjonsanalyse, på engelsk intention-to-treat analysis, er en statistisk analyse der alle pasienter som er tiltenkt å starte med en behandling inkluderes, også de som ikke starter eller ikke fullfører. Dette til forskjell fra per-protokoll-analyse, som tar med bare de som fullfører en spesifikk behandling.

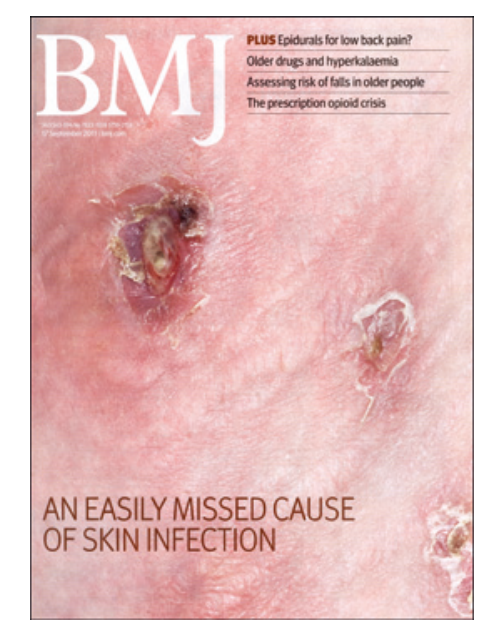

Artikkelen ble publisert 13.9. 2011 i BMJ (www.bmj.com), som regnes som en av de «fem store» innen medisinsk publisering, ved siden av New England Journal of Medicine, JAMA, Annals of Internal Medicine og The Lancet 